\section{DERECHOS QUE SUJETAN, SUJETOS DE DERECHO BAJO EL PRIMER PERONISMO MERCEDES BARROS}

Mercedes Barros es docente en la Facultad de Ciencia Política y Relaciones Internacionales de la Universidad Católica de Córdoba e investigadora del CONICET. Av. Armada Argentina 3555, (X5016DHK) Córdoba, Argentina.

e-mail: mercedesbarros@gmail.com

\section{Resumen}

Este artículo estudia el lenguaje de derechos bajo el primer peronismo para lo cual se plantea un doble objetivo. En primer lugar, se propone explicar la ruptura que el gobierno peronista del período 1946-1955 implicó en materia de derechos. Sostendremos que la proclamación e institución de nuevos derechos sociales, no sólo amplió beneficios materiales y simbólicos para los trabajadores, sino que además trajo consigo un nuevo lenguaje que puso en cuestión los usos y sentidos alrededor de los derechos de los individuos que habían dominado el imaginario político de las primeras décadas de la Argentina moderna. Los usos y desusos de aquel nuevo lenguaje tuvieron efectos significativos a nivel de los destinatarios de los nuevos derechos. El segundo propósito del artículo es entonces abordar ese proceso subjetivo de rasgos complejos y autónomos que se dio a nivel de la recepción discursiva de este nuevo lenguaje. El peronismo propició un sujeto de derechos que si bien gozó y se sujetó a los derechos otorgados, exigió y forzó los límites de los derechos ya consagrados e instituidos, reclamando por los que estaban por venir.

\section{Summary}

This paper studies the language of rights under first Peronism, and to do that it has a twofold objective. In the first instance, it aims to account for the rupture that the Peronist government (19461955) brought about in respect to rights discourse. As it will be argued, during those years the declaration and institutionalization of new social rights, not only expanded material and symbolic benefits for workers, but it also bring into play a new language that questioned the meanings and uses around rights that had prevailed in the political imaginary during the first decades of modern Argentina. The new language and its new uses and disuses had significant effects at the level of addressees of new rights. The second purpose of this article is then to analyze this subjective process of autonomous and complex aspects that took place at the level of the discursive reception. Peronism motivated a subject of rights that even if it subjected itself to the rights already obtained, it also demanded and forced the limits of the already consecrated and institutionalized rights, claiming for those still to come. 